
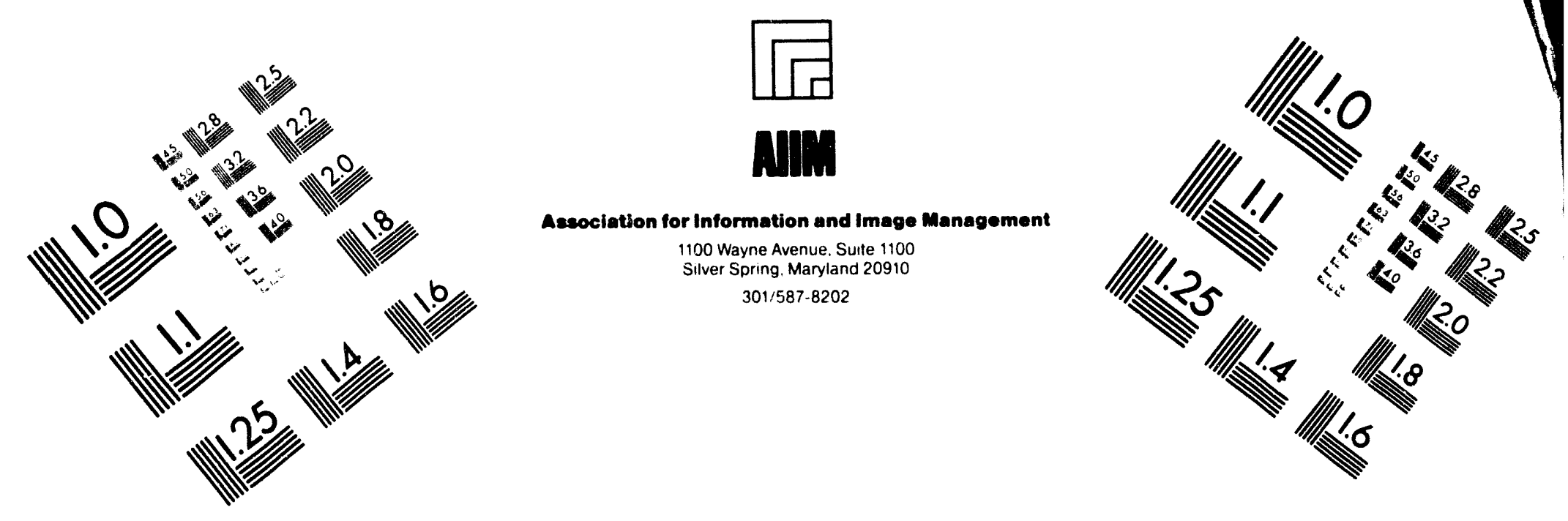

\title{
Centimeter
}

$\begin{array}{lllllllllllllll}1 & 2 & 3 & 4 & 5 & 6 & 7 & 8 & 9 & 10 & 11 & 12 & 13 & 14 & 15 \\ 15 m\end{array}$

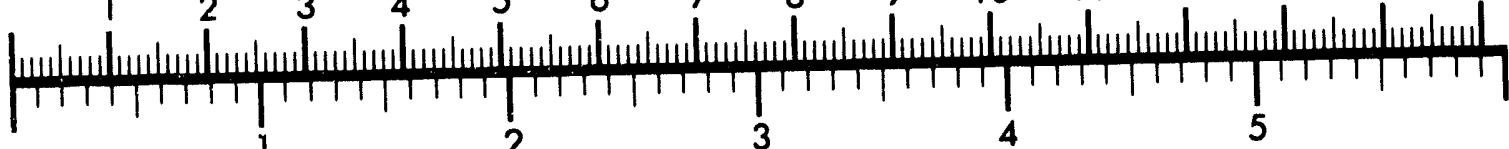
Inches

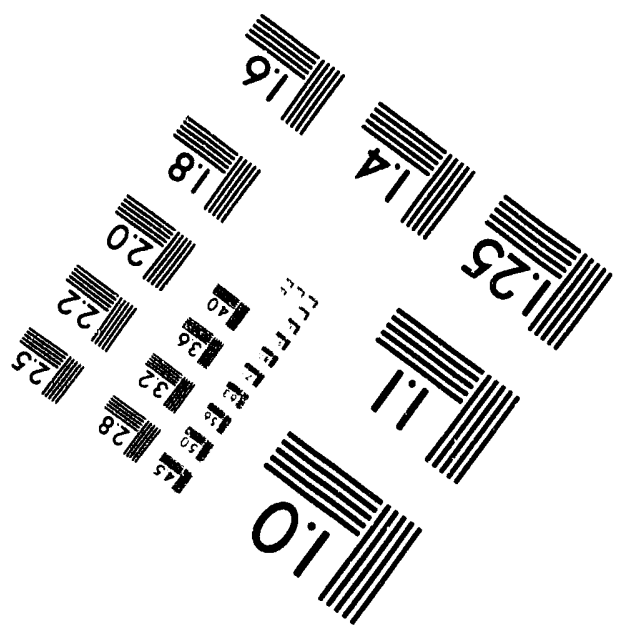

MANUFACTURED TO AIIM STANDARDS

BY APPLIED IMAGE. INC.

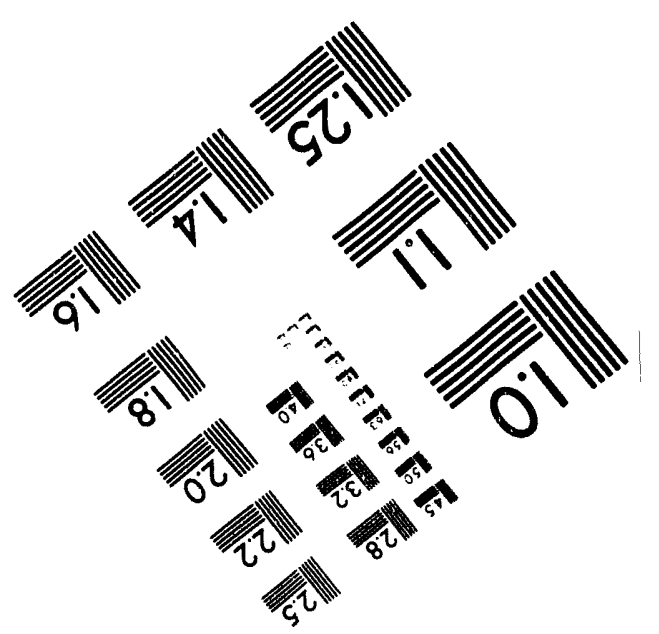



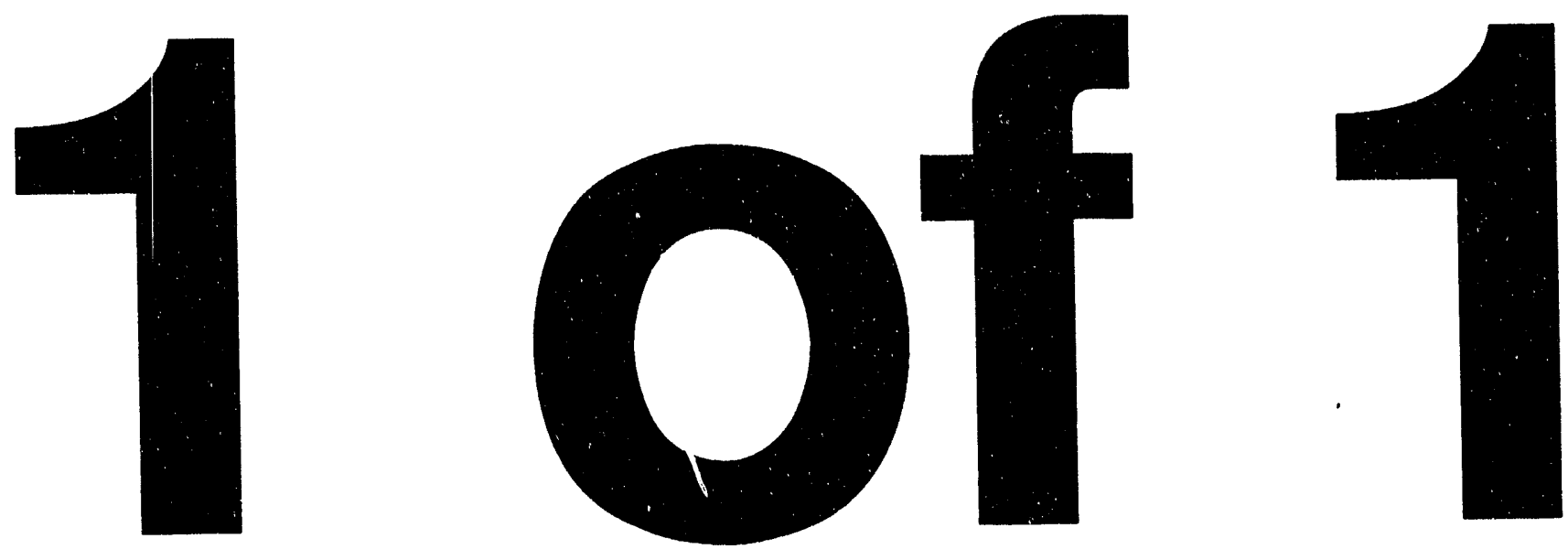


\section{AIR TOXICS FROM HEAVY OIL PRODUCTION AND CONSUMPTION}

F.W. Lipfert, M. P. DePhillips, and P.D. Moskowitz

December 22, 1992

Prepared for

Dr. Brent Smith

U.S. Department of Energy

Metairie Site Office

New Orleans, LA

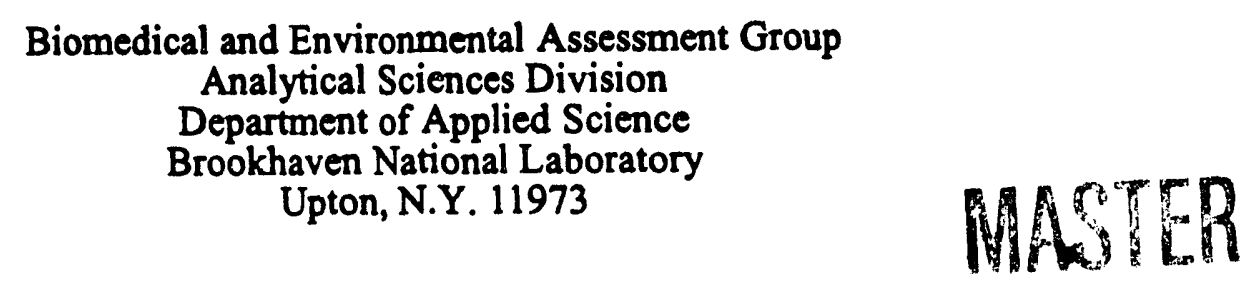

This research was performed under the auspices of the United States Department of Energy under Contract

No. DE-AC02-76CH00016 


\section{DISCLAIMER}

This report was prepared as an account of work sponsored by an agency of the United States Government. Neither the United States Government nor any agency thereof, nor any of their employees, not any of their contractors, sub- contractors, or their employees, makes any warranty, express or implied, or assumes any legal liability or responsibility for the accuracy, completeness, or usefulness of any information, apparatus, product, or process disclosed, or represents that its use would not infringe privately owned rights. Reference herein to any specific commercial product, process, or service by trade name, trademark, manufacturer, or otherwise, does not necessarily constitute or imply its endorsement, recommendation, or favoring by the United States Government or any agency, contractor, or subcontractor thereof. The views and opinions of authors expressed herein do not necessarily state or reflect those of the United States Government or any agency, contractor or subcontractor thereof. 


\begin{abstract}
This report assesses the potential impact of recent Federal and state regulations for airborne toxic substances on the production and consumption of heavy fuel oils. Emissions of nickel from heavy oil production in California are considered in some detail, in conjunction with California state regulations for toxic emissions. Although the lise of thermal energy from heavy crude oils could in theory be impacted by toxic air pollution regulations, recent trends towards the use of natural gas for the required extraction energy appear to provide substantial relief, in addition to reducing emissions of criteria air pollutants. However, the consumption of residual fuel oils containing toxic metals could result in higher population exposures to these substances and their attendant risks may be worthy of more detailed analysis.
\end{abstract}




\section{CONTENTS}

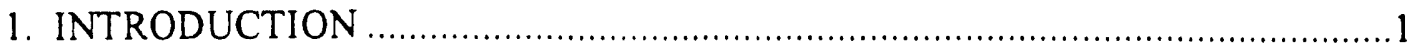

2. CHARACTERISTICS OF HEAVY CRUDE OIL ….........................................

2.1 Chemical Composition .........................................................................

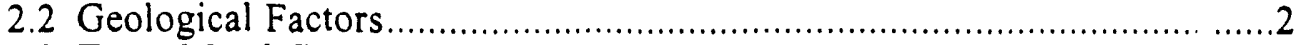

2.3 Trace Metal Content .......................................................................... 2

3. HEAVY OIL RESOURCES AND PRODUCTION ...........................................5

3.1 Definition and Historical Production Levels ........................................ 5

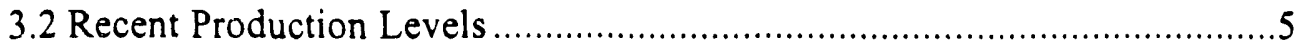

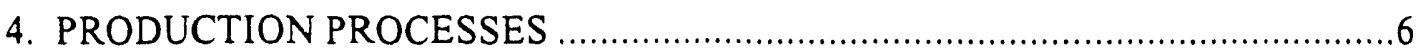

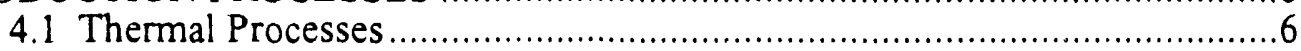

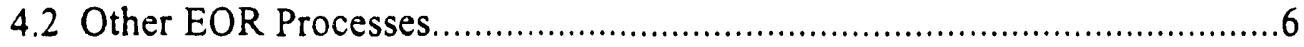

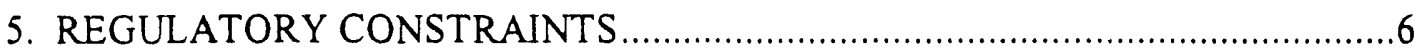

5.1 Title III of the (Federal) CAAA ......................................................... 7

5.2 California "Hot Spots" Regulation .......................................................

5.2.1 Source Categories and Reporting Requirements .....................9

5.2.2 Emission Inventory Plan and Reports.................................9

5.2.3 Risk Assessment ......................................................................10

5.3 Summary of Potential Regulatory Constraints ......................................11

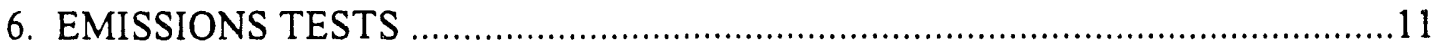

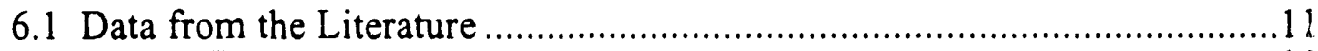

6.2 Recent Test Data ...........................................................................

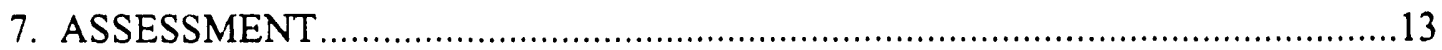

8. METAL EMISSIONS FROM PETROLEUM CONSUMPTION ........................13

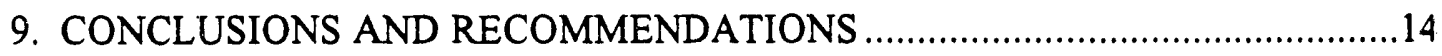

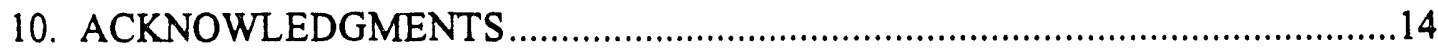

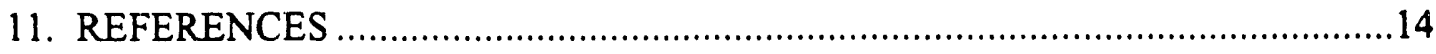

TABLES

1 Typical Crude Oil Trace Metal Contents .............................................................

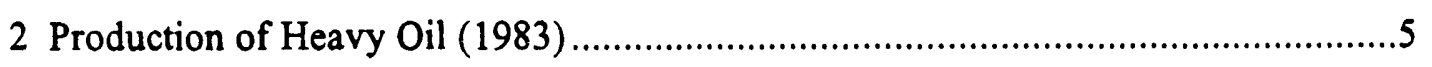

3 Hazardous Air Pollutants as Defined in California and by the US EPA ..................8

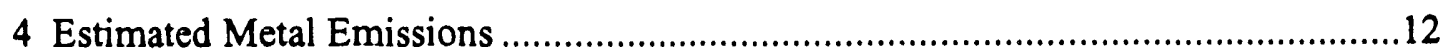

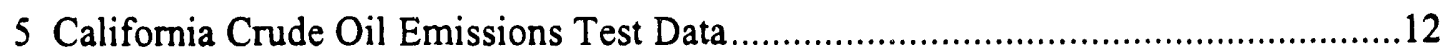




\section{FIGURES}

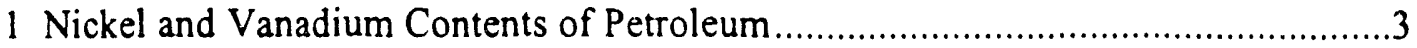

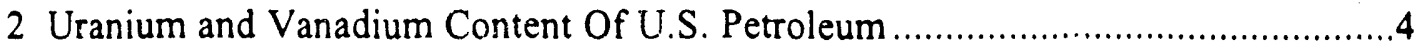

3 Frequency Distribution of Petroleum Nickel Content ............................................4 


\section{INTRODUCTION}

Heavy oils constitute an important portion of the world's petroleum reserves, especially in the Western Hemisphere. These resources are characterized by low values of API gravity (250 or less), which can make extraction difficult. Heavy petroleum occurs as tar sands (primarily in Alberta, Canada) and as heavy crude oils. Most of the U.S. production is in the form of heavy crudes, primarily in California. There are also important resources in Venezuela; for example, California and Venezuela together produced $76 \%$ of the world total in 1984 (Unitar, 1984). The economic security which derives from domestic petroleum resources increases the value of these heavy petroleum resources, especially during times of chaos in the Middle East.

Disadvantages of heavy petroleum usage include its high sulfur and trace metal contents, and the large amount of energy required for extraction. The standard extraction practice in California involves using a substantial portion of the extracted crude in steam generators to supply thermal energy directly to the wells (for every 100 increase in temperature, the oil viscosity is cut in half (Hocott, 1979), thus easing extraction). California air pollution control rules require these boilers to be fitted with scrubbers to remove $\mathrm{SO}_{2}$ from the flue gases. Low $\mathrm{NO}_{\mathrm{x}}$ burners are also used, but the typically low ash contents of oil would not automatically dictate use of particulate control devices. Thus, particulate trace metals in petroleum could be essentially uncontrolled. Recent developments in the San Joaquin Valley of California suggest that natural gas has become the fuel of choice (Erickson, 1992).

Recent emphasis at both state and Federal levels on control of hazardous air pollutant (HAP) emissions has the potential to impose further environmental controls on U.S. production of heavy crudes. Many of the trace metals characteristic of heavy crude are classified as HAPs, notably arsenic, mercury and nickel. To the extent that production cost and feasibility could be affected by constraints on trace metal emissions, these fuels could lose their competitive position in favor of foreign sources, which also contain trace metals. The environmental burden could thus be shifted from the production source, where it is concentrated, to end uses, where it is much more diffuse and less likely to be regulated under present statutes.

This report describes heavy fuel resources and their chemical characteristics, the current regulatory framework for control of toxic emissions, and the results and implications of recent tests of emissions of toxic compounds from California oil field steam generators. The report focuses on California because of its State regulations on HAPs and because most of the U.S. heavy crude production is located there. Analyses are presented of the relative impact of the use of petroleum products on ambient trace metal levels. Recommendations for a risk analytic approach to the problem are included in the discussion of research needs.

\section{CHARACTERISTICS OF HEAVY CRUDE OIL}

Heavy petroleum is defined by its API gravity and commonly includes heavy crudes, tar sands, and bitumen. Specific gravities of heavy crudes are in the range 0.93-1.00; bitumens and "extra-heavy" crudes have specific gravities in excess of 1.0. This report emphasizes heavy crudes, since they constitute an important part of the U.S. production of this class of petroleums.

\subsection{Chemical Composition}

One index of fuel chemistry is the hydrogen/carbon atomic ratio, which varies from 4.0 for natural gas (methane) to about zero for coal. Lighter crudes are around 1.8 and heavier crudes are around 1.5 (Speight, 1990). The hydrocarbon chemistries of light and heavy crudes also differ appreciably; larger molecules (polynuclear aromatics and polycycloparaffins) are found in the heavier crudes. Sulfur content tends to vary inversely with API gravity, from $0.04 \%$ by weight for the lightest crudes to a maximum of $5-6 \%$ for heavy fuels (Speight, 1990). Heavy crudes also contain more nitrogen, which contributes to $\mathrm{NO}_{\mathbf{x}}$ formation during 
combustion. The ranges of toxic metals found in petroleum extend from $0.0016-0.017 \mathrm{ppm}$ for chromium $(\mathrm{Cr}), 0.03-0.11 \mathrm{ppm}$ for antimony $(\mathrm{Sb}), 0.001-0.2 \mathrm{ppm}$ for lead $(\mathrm{Pb}), 0.63-2.54 \mathrm{ppm}$ for manganese $(\mathrm{Mn}), 0.001-12$ for cobalt $(\mathrm{Co}), 0.03-30 \mathrm{ppm}$ for mercury $(\mathrm{Hg})$, to $3-345 \mathrm{ppm}$ for nickel (Ni) (Speight, 1990; Smith et al., 1974). The highest range of metal content is for vanadium (5-1500 ppm), which is not listed as a HAP (see Table 1). Uranium is also found, but we have no information as to which isotope. The mean cadmium (Cd) content was estimated as $0.03 \mathrm{ppm}$, based on the mean zinc content (Smith et al., 1975). Concentrations can be appreciably higher in residual fuel oils.

Some of the metals occur as porphyrins, which are cyclic conjugated compounds such that four nitrogen atoms are bound to a large number of metal ions, thus forming highly stable metal chelates (Speight, 1990). This structure may explain why metals in petroleum often cannot be removed by filtration (arsenic may be an exception). It is thought that the source of petroleum porphyrins is chlorophyll in the original plant material. Many research questions still exist about the relative abundance of metal chelates and whether metals other than $\mathrm{Ni}$ and $\mathrm{V}$ occur in this mode. Nickel in petroleum occurs as poryphin and non-poryphin, the non-poryphin fraction increasing with asphaltene content.

\subsection{Geological Factors}

Petroleum occurs in various sedimentary rocks but heavy crudes are found only in certain specific geological locations. There is a relationship between rock types and crude oil types; oils found in carbonate rocks tend to be heavy (API $<200$ ), with high contents of asphaltenes, sulfur and metals. Those crudes found in shales will more nearly resemble conventional oils. Vanadium content tends to exceed nickel content in the higher sulfur crudes of marine origin, while the reverse is true for the lower sulfur crudes originating from lake deposits (Speight, 1990).

\subsection{Trace Metal Content}

Table 1 presents data on metal and ash contents of petroleums for both conventional and heavy crudes, by origin. Data on metal content are presented on two different bases: as a percentage of ash, and as originally present in the oil. Referencing metal content as ppm of oil seems to work better as a characterization tool since ash contents are quite variable. The data show that some of the trace metal contents tend to be correlated. As shown in Figure 1, nickel content is highly correlated with vanadium content; the California crudes stand out as having disproportionately high nickel content. Uranium content also correlates with vanadium, but at $\mathrm{ppb}$ concentration levels (Figure 2).

The distribution of nickel is seen to be bimodal, with one mode for light oils and another for heavy crudes (Figure 3). The bimodal distribution could be as a result of the presence of both porphyrin and non-porphyrin contributions. However, there is more overlap than one might have expected, which suggests that nickel emissions from combustion of petroleum products should be examined with regard to compliance with Federal and State statutes (see below). 
Table 1 Typical Crude Oil Trace Metal Contents

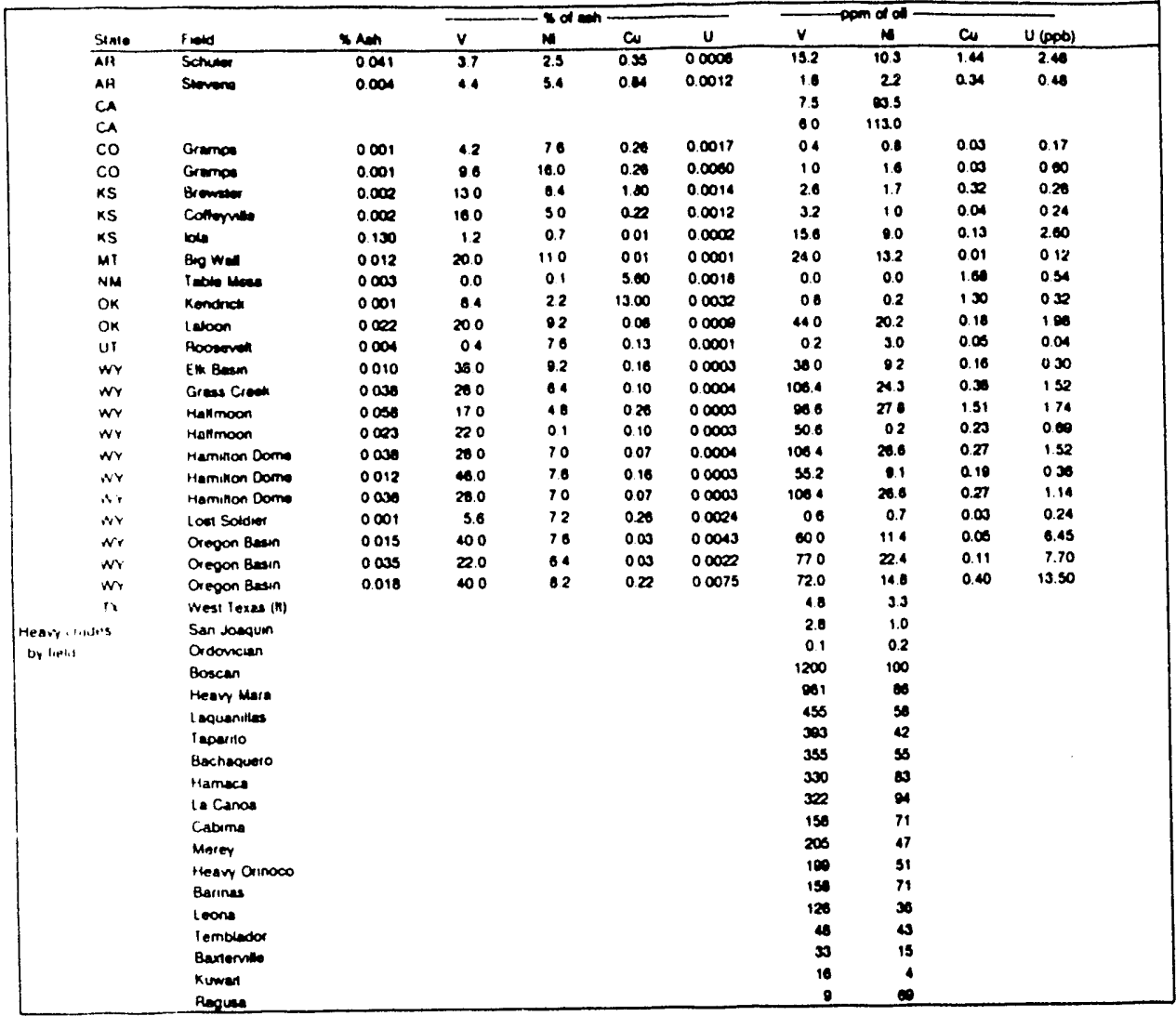

(data Itrim Yon, 1975

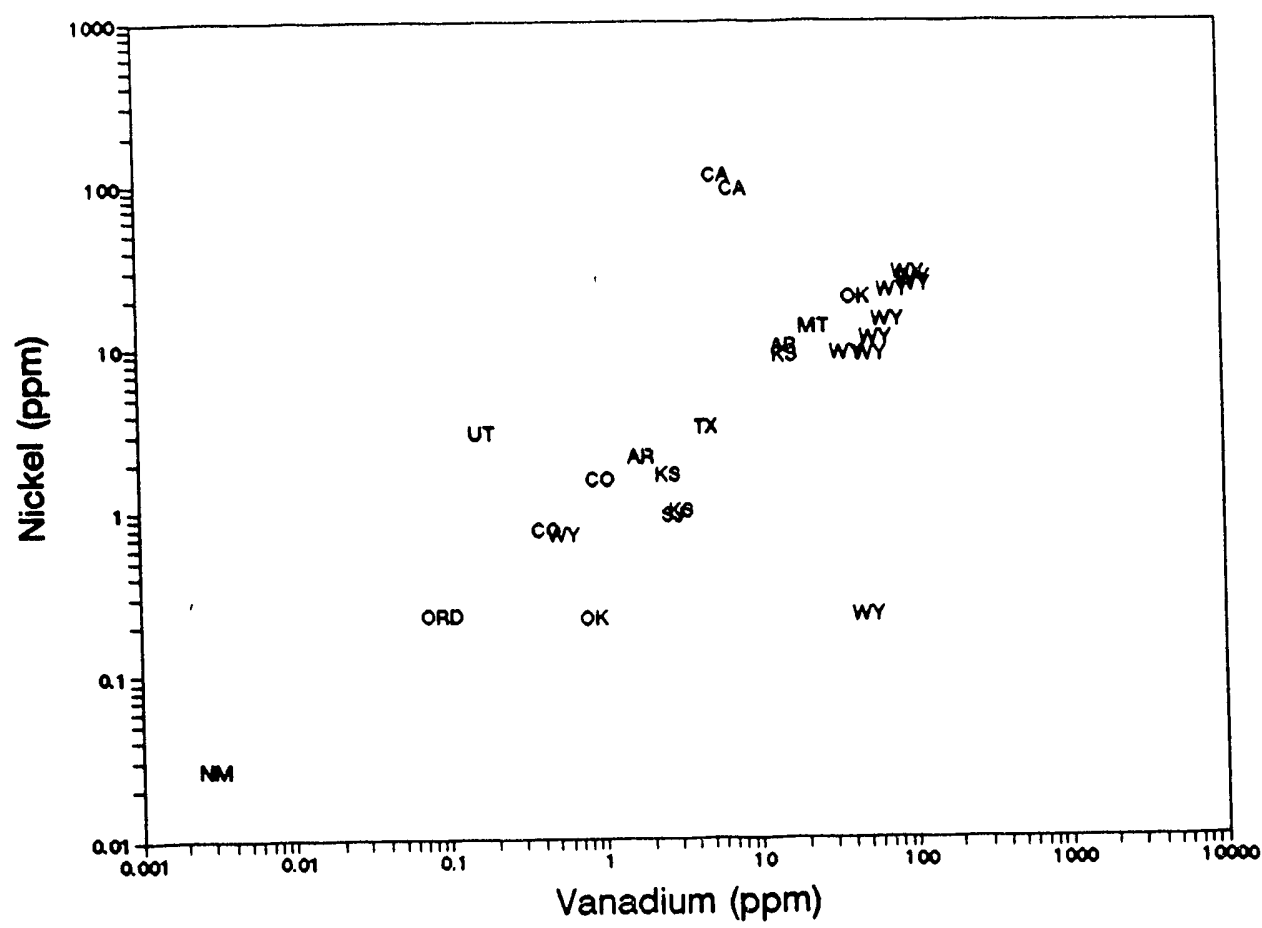

Figure 1 Nickel and Vanadium Contents of Petroleum 


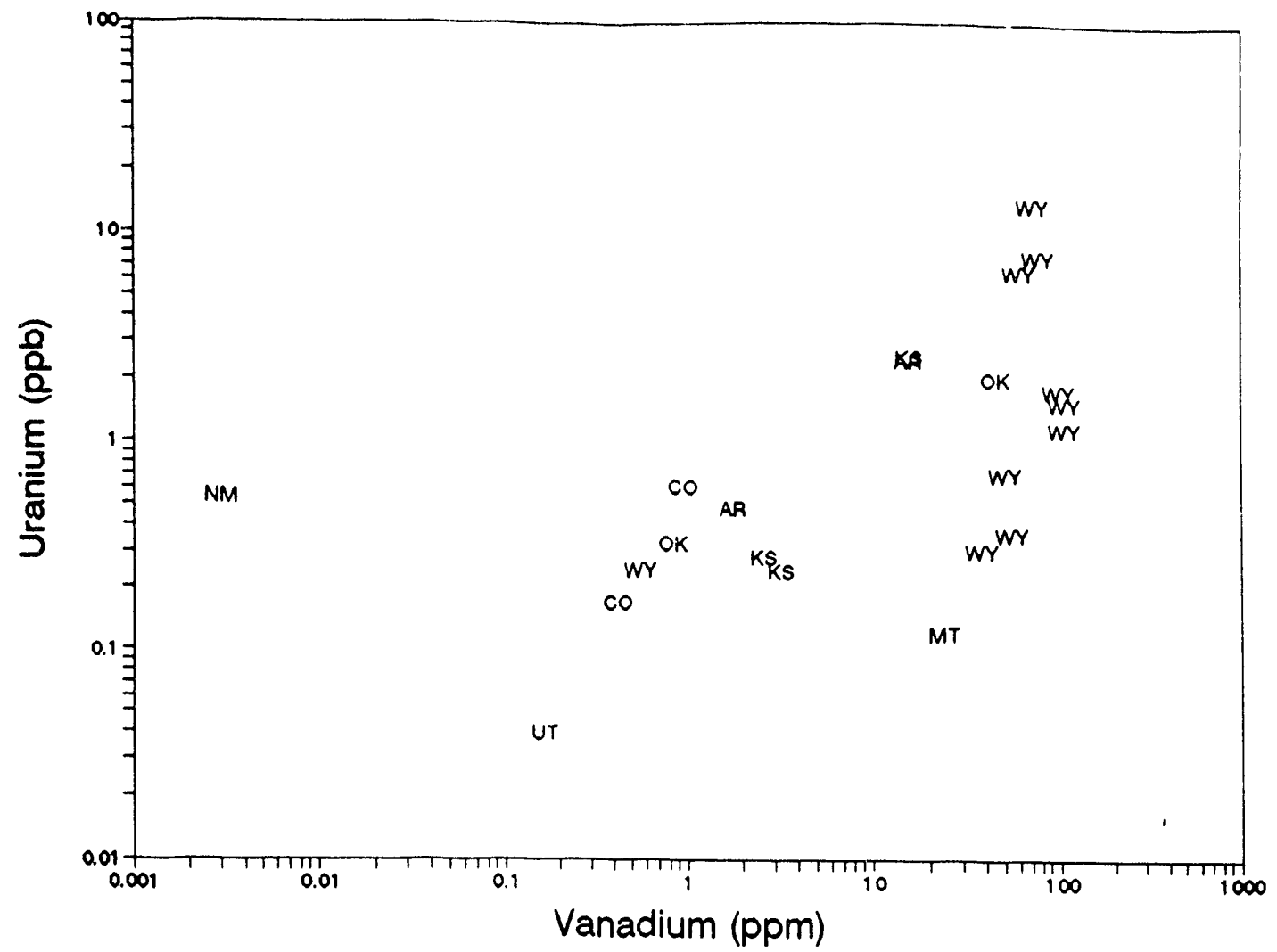

Figure 2 Uranium and Vanadium Content Of U.S. Petroleum

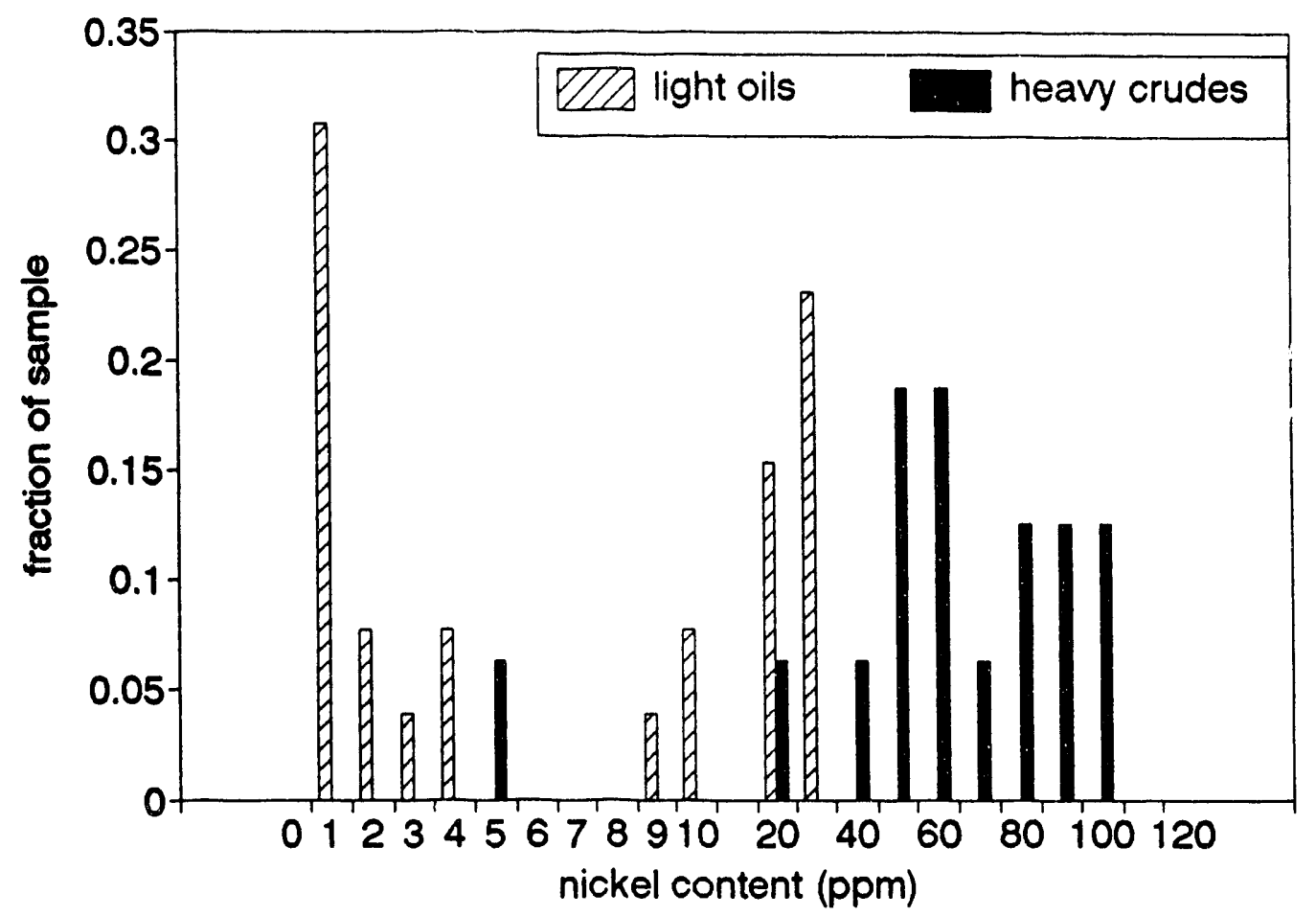

Figure 3 Frequency Distribution of Petroleum Nickel Content 


\section{HEAVY OIL RESOURCES AND PRODUCTION}

\subsection{Definition and Historical Production Levels}

U.S. resources of heavy crude oils were described in 1967 by the Bureau of Mines (BOM). The BOM study was confined to reservoirs containing heavy oils that are mobile at reservoir conditions. As of 1966 , the BOM estimated that 5.2 billion barrels of the resource of 45.9 billion stock-tank barrels (stb) were recoverable with the technologies of that time. The 1965 production was 372 million barrels, of which $6 \%$ was produced from thermal recovery operations. About $16 \%$ of the forecasted future production was expected to be recovered from thermal operations. The largest producing state in 1965 was California, which also had the highest percentage of thermal recovery operations. California heavy crude production was about 185 million barrels per year in the 1950s, declining slightly around 1960, and increasing again to about this same level. Only about $11 \%$ of 1965 California production was by means of thermal enhancement.

\subsection{Recent Production Levels}

At a 1979 conference, U.S. cumulative heavy oil production was put at about 8 billion barrels, of which $69 \%$ came from California and $16 \%$ from the East Texas-Arkansas-Louisiana region. The total recoverable resource was estimated at about 30 billion barrels (Meyer and Dietzman, 1979), which represents a substantial increase over the earlier estimate. At this same conference, California production was put at 182 million barrels per year, half of which by thermally enhanced recovery (Hallmark, 1979). 1989 crude oil production of all types in California was about 331 million barrels, of which about 8.3 million was consumed as part of the production process (Hutchins, 1992).

In 1984, the United Nations released the results of a world survey on heavy crudes and tar sands (Unitar, 1984). Data were included on oil fields, reserves, production, depth, API gravity, viscosity, and recovery methods. Thermal recovery methods were heavily used only in California. Annual U.S. production data for 1983 are given in Table 2.

\section{Table 2. Production of Heavy Oil (1983)}

\begin{tabular}{|l|l|}
\hline State & $106 \mathrm{bbl}$ \\
\hline \hline $\mathrm{AL}$ & 0.5 \\
\hline $\mathrm{CA}$ & 220. \\
\hline $\mathrm{KS}$ & 1.1 \\
\hline $\mathrm{MI}$ & 0.01 \\
\hline $\mathrm{MS}$ & 6.84 \\
\hline $\mathrm{MO}$ & 0.19 \\
\hline $\mathrm{NM}$ & 0.47 \\
\hline $\mathrm{TX}$ & 5.17 \\
\hline
\end{tabular}

For comparison, Venezuela produced 276 million barrels of heavy crude, and Venezuela and California together produced $76 \%$ of the world total. Bitumen production was almost all from Alberta, Canada. 


\section{PRODUCTION PROCESSES}

Heavy crudes are extracted using a variety of processes which are collectively known as "enhanced oil recovery " (EOR). Some of the common EOR methods are also used to extract oil from fields in which the natural reservoir pressures have been depleted by primary production (Kaplan et al., 1983).

\subsection{Thermal Processes}

The common thermal EOR processes include stearn soaking, steam injection, and in-situ combustion. Steam soaking and steam injection both utilize external steam generators which usually fire a portion of the crude oil and differ only in the cycles used to supply the thermal energy. The major thermal EOR process is steam flooding, which has the advantage of faster responses times and high recovery ratios, but requires large amounts of high-quality feedwater. Oil-field steam generators have been subject to pollution controls in California for some time, principally $\mathrm{SO}_{2}$ scrubbers. It is common to burn one-third of the vil extracted, so that emissions may be estimated by taking half of the net production (Kaplan et al., 1983). The unit sizes for these package boilers are generally $62.5 \mathrm{MBtuh}$ or less, but they are often ganged together to provide a total facility of the order of $300 \mathrm{MBtuh}$.

In-situ combustion relieves the water supply problems inherent in steam generation but can have serious operational problems (Van Poollen and Associates, Inc., 1980). Air emissions from in situ combustion are not well characterized but appear to consist mainly of hydrocarbons and particulates. On the basis of emissions per barrel of crude produced, these values appear to be somewhat higher than would be obtained with a well-controlled external boiler. There are also some emissions involved when the air compressors supplying combustion air to the well are powered by internal combustion engines, but these usually do not fire crude oil (Kaplan et al., 1983).

\subsection{Other EOR Processes}

The other two groups of EOR processes are chemical and miscible displacement processes. Chemical methods include alkaline flooding, polymer flooding, and micellarpolymer flooding; the intent is to improve the transport properties of the oil. Miscible displacement involves injecting gases which are soluble in oil, which then increases the flow of oil through the reservoir. Since not all of these methods are applicable to heavy crude production and they do not appear to involve increased air emissions, they will not be considered further.

\section{REGULATORY CONSTRAINTS}

The burning of heavy crude oil results in the emission of a number of hazardous air pollutants, especially nickel, as discussed in detail below. This section explores Federal and State regulations applicable to these emissions. Title III of the (Federal) Clean Air Act Amendments of 1990 (CAAA) governs national emission standards for 189 listed hazardous air pollutants. California's Air Toxic "Hot Spots" Information and Assessment Act of 1987 and its Amendments of 1990 require and regulate the testing, reporting and assessment of risk from 326 listed hazardous air pollutants, which are classified into two categories: substances for which emissions must be quantified, and substances for which production, use, or other presence must be reported

The pollutants of interest here are the trace metals which occur naturally in petroleum and which are found in the ash from petroleum combustion. Table 3 lists the metals which are found in petroleum, accoraing to two different references, and the metals and metallic compounds which are listed as HAPs by the CAAA and by the State of California. Very little is 
known about the specific metallic compounds emitted from oil combustion, but it is unlikely that base metals would be found, as opposed to their oxides or salts.

\subsection{Title III of the (Federal) CAAA}

Oil exploration or production wells, pipeline compressors and pumping stations (all of which are users of heavy crude oil) are given special consideration within the CAAA, pursuant to Section 301, Subsection " $n$ ". In contrast to Section 301, Subsection a(1), which defines a "major source" as any stationary source or group of stationary sources located within a contiguous area and having the capability of emitting in excess of 10 tons per year (tpy) of any one listed pollutant or 25 tpy for any combination of listed pollutants, Subsection " $n$ " states that emissions from these oil combustion sources cannot be combined to determine whether such units constitute "major sources."

Subsection " $n$ " also provides special conditions regarding the classification of these sources as "area sources." In contrast to Section 301 Subsection a(2) which defines an "area source" as any stationary source that is not a "major source," these oil combustion sources must be in close proximity to a metropolitan area with a population greater than one millior. and the EPA must deiermine that they will present more than a "negligible risk of adverse effects to public health."

Oil-field steam generators are commonly aggregated to comprise facilities of up to about 300 MBtuh capacity. For oil with a nickel content of $60 \mathrm{ppm}$ (the California average), the uncontrolled $\mathrm{Ni}$ emission rate from such a facility would be about $1 \mathrm{lb} / \mathrm{h}$ or about 4 tpy. Thus it is unlikely for an individual source to emit in excess of 10 tpy, or 25 tpy combination, of the listed hazardous air pollutants. Further, most of these sources are located in areas with neighboring populations iess than one million (e.g., the Bakersfield MSA population is about half that) or offshore; therefore, they will not be considered "area sources." It thus appears that the CAAA will not apply to these primary users of heavy oil.

\subsection{California "Hot Spots" Regulation}

Primary users of heavy crude oil must comply with California's Air Toxics "Hot Spots" Information and Assessment Act of 1987 (the Act) of Health and Safety Code, Sections 44300 et. seq., and its 1990 Amendments entitled, "Emission Inventory Criteria and Guidelines Regulations (Amendments)," California Code of Regulations Subchapter 7.6, sections 93300 through 93347. The goals of the Act are to collect site-specific information to ascertain the nature and quantities of emissions of over 300 toxic air pollutants throughout California. Also, the Act seeks to develop health risk assessments for certain facilities that each local Air Pollution Control District Authority (District) may designate as having emissions which may result in adverse public health impacts, and to make the health risk assessment information available to the public.

The Act requires any facility which manufactures, formulates, uses or releases or has the potential to release total organic gases, particulates, or oxides of nitrogen or sulfur $\left(\mathrm{NO}_{\mathrm{x}}\right.$ and $\mathrm{SO}_{\mathrm{x}}$ ), to submit emission inventory plans and emission inventory reports to the districts. Facilities that emit under 10 tpy and are listed in Appendix E-II of the Act are exempt from submitting these plans and reports but must, however, complete and submit to the district preprinted schedules and reports. Criteria and guidelines for completing these reports are set forth in the Act's Amendments and subsequent guidance documents. 
Table 3 Hazardous Air Pollutants as Defined in California and by th: US EPA HAP Regulation

\begin{tabular}{|c|c|c|c|c|c|}
\hline Substance & Cal Ia & Cal IIb & USEPA & $\begin{array}{|ll|}\begin{array}{l}\text { Smith } \\
\text { al. }\end{array} & \text { et } \\
\end{array}$ & Speight \\
\hline Al compounds & & & & $\mathrm{X}$ & \\
\hline Sb compounds & & & $\bar{X}$ & $\bar{X}$ & \\
\hline As compounds & $\mathbf{X}$ & & $\bar{X}$ & $\bar{X}$ & \\
\hline As & $\mathbf{X}$ & & & & \\
\hline Ba compounds & & & & $\bar{X}$ & $\overline{\mathbf{X}}$ \\
\hline $\mathrm{Be}$ & $\bar{X}$ & & & & \\
\hline Be compounds & & & $\bar{X}$ & & \\
\hline B compounds & & & & $\mathrm{X}$ & $\mathbf{X}$ \\
\hline $\mathrm{Cd}$ & $\underline{X}$ & & & & \\
\hline Cd compounds & $\bar{x}$ & & $\bar{X}$ & $\bar{X}$ & \\
\hline Ca compounds & & & & & $\bar{X}$ \\
\hline Ce compounds & & & & & $\bar{X}$ \\
\hline Cr compounds & & & $\bar{X}$ & $\bar{X}$ & \\
\hline CrVI compounds & $\bar{X}$ & & & & \\
\hline Co compounds & & & $\bar{X}$ & $\bar{X}$ & $\bar{X}$ \\
\hline $\mathrm{Cu}$ & $\bar{X}$ & & & & \\
\hline Cu compounds & & & & $\mathbf{X}$ & $\bar{X}$ \\
\hline Ga compounds & & & & & $\mathbf{X}$ \\
\hline Fe compounds & & & & $\bar{X}$ & $\mathbf{X}$ \\
\hline $\mathrm{Pb}$ & $\mathbf{X}$ & & & & \\
\hline $\mathrm{Pb}$ compounds & & & $\bar{X}$ & $\bar{X}$ & $\bar{X}$ \\
\hline Pb compounds (inorg) & $\bar{X}$ & & & & $\mathrm{X}$ \\
\hline Mr compounds & & & & & \\
\hline $\mathrm{Mn}$ & $\mathbf{X}$ & & & & \\
\hline Mn compounds & & & $\bar{X}$ & $\bar{X}$ & \\
\hline $\mathrm{Hg}$ & $\mathbf{X}$ & & & & \\
\hline Hg compounds & & & $\mathbf{X}$ & $\mathbf{X}$ & $\bar{X}$ \\
\hline Mo compounds & & & & $\mathbf{X}$ & \\
\hline $\mathrm{Ni}$ & $\bar{X}$ & & & & \\
\hline Ni compounds & & $\bar{X}$ & $\bar{X}$ & $\mathbf{X}$ & $\mathbf{X}$ \\
\hline $\mathrm{Ni}(\mathrm{CO})_{4}$ & $\bar{X}$ & & & & \\
\hline $\mathrm{Ni} 2 \mathrm{~S}_{2}$ & $\mathbf{X}$ & & & & \\
\hline Se & $\mathbf{X}$ & & & & \\
\hline Se compourids & $\mathbf{X}$ & & $X$ & $\bar{X}$ & \\
\hline Ag compounds & & & & $\mathrm{X}$ & \\
\hline Sr compounds & & & & & $\mathrm{X}$ \\
\hline Sn compounds & & & & $\mathrm{X}$ & $\mathrm{X}$ \\
\hline Sn compounds & & & & & $\bar{X}$ \\
\hline Ti compounds & & & & & $\mathbf{X}$ \\
\hline V compounds & & & & $\mathbf{X}$ & $\mathbf{X}$ \\
\hline $\mathrm{Zn}$ & $\mathbf{X}$ & & & & \\
\hline $\mathrm{ZnO}$ & $\bar{X}$ & & & & \\
\hline $\mathrm{Zn}$ compounds & & & & $\mathbf{X}$ & $\bar{X}$ \\
\hline $\mathrm{Zr}$ compounds & & & & & $\mathbf{X}$ \\
\hline
\end{tabular}

a substances for which emissions must be quantified

b substances for which production, use, or other presence must be reported 


\subsubsection{Source Categories and Reporting Requirements}

The statute identifies three categories of facilities: (1) those that release 25 tpy or more of total organic gases, particulate matter, $\mathrm{NO}_{\mathrm{x}}$ and $\mathrm{SO}_{\mathrm{x}},(2) 10$ tpy or more but less than 25 tpy, and, (3) those that emit less than 10 tpy. Facilities that emit more than 10 tpy shall submit an emission inventory plan to the appropriate district by the following August 1 after the commencement of operation or an increase in emission levels. Further, any facility that manufactures, formulates, uses, or releases any substance added to the list on or before April 1 of a given year shall include that substance in any subsequent emission inventory plan or report required. These facilities are exempt from submitting individual plans and reports if the operators are notified in writing that the facility's emission data will be included in an industrywide inventory prepared by the district.

Facilities that manufacture, formulate, use, or release less than 10 tpy of each air toxic are divided into two categories which are listed in Appendices E-I and E-II (Table III) to the Amendments. The facilities listed in appendix E-I must prepare complete emission inventory plans and reports. Facilities listed in appendix E-II (e.g., crude petroleum and natural gas extraction and drill and oil wells) are required complete a survey of production, use or other presence of listed substances. E-II facilities shall submit to the appropriate district, in lieu of a plan and a report, a completed copy of the Facility Description Form and a completed copy of Form S-UP (Appendix 1 and Appendix 2) which includes all applicable listed substances. Included on Form S-UP, or on an attachment therewith, the operator should briefly describe the nature and approximate quantity of the indicated use, production or other presence of each applicable substance. These completed forms must be submitted to the district on or before the August 1, following the commencement of operation on or before the previous January 1.

\subsubsection{Emission Inventory Plan and Reports}

Since facilities burning heavy crude oil emit in excess of the minimum reporting requirements for 326 hazardous air pollutants set forth by the Act, each fariity should be submitting Emission Inventory Plans and Reports. For purposes of inventorying and reporting emissions under the regulation, the current list of 32.6 is divided into two groups which differ in their requirements for emission inventory reporting. For substances in the first group (i.e., substances for which emissions must be quantified) all emissions must be quantified to the degree of accuracy specified in the regulation. Facilities that use or produce substances in the second group need only indicate whether the substance is produced, used or otherwise present at their facility.

The site specific emission inventory plan is a facilities commitment as to how it will quantify its emissions of listed substances. Each emission inventory plan must specify in detail how the facility operator will inventory the facility's emission of all toxic substance on the list of substances subject to the Act. Also, the plan must explain in detail a facilities approach to calculating and/or collecting emission data from all points of actual or must comply with the criteria and guidelines set forth in the Act. Specific instructions for completion of this plan is described in Article 3 sections 93310-93315 of the Amendments.

Each inventory plans must include a schematic flow diagram describing all process flows that affect the nature or quantity of emissions of regulated substances. Section 93311 gives a detailed description of the required contents of the diagram. This includes, but is not limited to:

* Clearly labeled blocks representing all devices associated with an emitting process within a facility (e.g., boilers, IC engines, incinerators, etc.).

* Specific emitting processes.

- An estimate number of valves, vents, flanges, seals and gaskets associated with each listed substance at the general locations of fugitive emissions.

* All stacks vents, ducted building exhaust sites and other sites of exhaust release of a listed substance. 
- Interconnections showing functional relationships that affect emissions or their reportable characteristics, sufficient to support evaluations regarding the completeness and representatives of each required source test protocol and inventory plan, (e.g., devices, stacks, emitting processes etc.).

* All major modifications to existing processes or devices anticipated to result in a significant change in the amount or nature of emissions which are expected to occur during the reporting period.

Further, for each emission point on the flow diagram the operator must identify the listed substance being emitted and specify in detail the estimation method, source test method or other measurement method that will be used to quantify the air releases. The plan must also include a source test protocol which describes how each source test method will be applied to each emission point.

After a district approves a plan, the facility operator must implement the plan within 180 days and submit an emission inventory report which presents the required emission data, a facility diagram and other required information. Reporting requirements, blank reporting forms, and instructions are included in the Amendments. Within 90 days of receipt of the report, the district will review the report, obtain any necessary corrections and clarification of the data and notify appropriate agencies. The district will then evaluate the data contained in the reported and categorize the facility based on potency, toxicity, quantity, and volume of the hazardous materials released. Those facilities designated as a high priority must subsequently prepare health risk assessments.

Emission inventory reports are submitted to the district within 180 days after approval of the plan. These reports include a facility diagram, results of all source tests, material analysis and other measurements performed. Also due within this time frame are completed copies of all required forms. A comprehensive listing of requirements and applicable forms is given in Article 4, Sections 93320-93324 of the Amendments.

The Article stipulates that each facility subject to the regulation must complete the following reporting forms: Facility Description Form (Appendix 2), an entry on a Stack Data Form (Appendix 3) for each stack or vent from which a listed substance may be released, an entry on a Device Description and Device-Stack Relations Form (Appendix 4) for each device associated with a release of a listed substance, and a Process and Emittants Data Form (Appendix 5) for each emitting process within the device. Also Form S-UP must be completed for all required substances. A list of further, more sitespecific, data required is given in section 93323.

\subsubsection{Risk Assessment}

All facilities that emit in excess of 25 tpy will be divided into three additional categories for the purpose of risk assessments. The State Board and the State Department of Health Service will, within 90 days of review of all emissions inventory data, place each facility in either a high, intermediate or low category. This evaluated priority is based on, but not limited to, the potency, toxicity, quantity, and volume of the hazardous materials released. The facilities that have been assigned to the highest category will, within 150 days of this designation, complete and submit to the district a health risk assessment.

Facilities that emit less than 25 tpy but more than 10 tpy and facilities that emit less than 10 tpy may also be included in the highest priority category by the district after reviewing all emission inventory data. In such a case, the district may therefore request these facilities to complete and submit health risk assessments.

All health risk assessment are submitted to the State Department of Health Service for review and comments. Upon the completion of this review process, the facility operators have 60 days to further modify the health risk assessment. Upon final approval the operator of the facility shall notify all exposed persons regarding the results of the health risk assessment if results indicate there is sufficient health risk associated with emissions from the facility. 


\subsection{Summary of Potential Regulatory Constraints}

The Federal regulations for HAPs have the potential to impose emissions controls on oil field steam generators, but these facilities have been specifically exempted from the most stringent portions of the CAAA. At present, it appears that the primary impact of the State regulations is that of collecting information. To the extent that there are costs involved in obtaining and reporting the required data, oil production costs could conceivably be increased. Also, it is conceivable that the outcome of a health risk assessment c ould result in requirements for reduced production or emissions.

\section{EMISSIONS TESTS}

\subsection{Data from the Literature}

Air pollution from oil-field steam generators has been a matter of concern in California for some time with respect to "criteria" air pollutants, primarily $\mathrm{SO}_{2}, \mathrm{NO}_{\mathrm{X}}$, and particulates. Kaplan et al. (1983) provide data on these pollutants, plus a range of trace metal emissions to be expected. Estimated metal emissions based on firing $1.5 \%$ sulfur content Kern crude oil are given in Table 4 (data expressed as percentages of the total particulate emissions and as tons/y). These data indicate an upper limit of about 3 tpy for all HAP emissions from a facility of 300 MBtuh capacity operating year round, of which the bulk is nickel.

Table 5 presents fuel composition data that may be used to estimate air emissions from firing California crude oils. The average nickel content is about $61 \mathrm{ppm}$; this would result in an annual emission rate of about 4 tpy of nickel for a 300 MBtuh facility, assuming that none the nickel was retained within the boilers. Based on the 1983 heavy oil production of 220 million tons statewide, an upper limit for California nickel emissions would be about 1100 tons.

\subsection{Recent Test Data}

Osborne and McDannel (1990) reported on emissions tests and fuel analyses of a steam generator firing crude oil, equipped with an $\mathrm{SO}_{2}$ scrubber, and on an IC (diesel) engine, conducted under under California's "Hot Spots" program (AB2588). The emissions tests included: total polycyclic aromatic hydrocarbons (PAH), benzene, formaldehyde, and trace metals. Radionuclides were also evaluated in the fuel. The fuel types used were not specified in the emissions test report, which made it impossible to correlate these data with the fuel analyses. Only $\mathrm{Ni}(28-84 \mathrm{ppm})$ and $\mathrm{Zn}(2.5-17 \mathrm{ppm})$ were present in the crude oil samples in any appreciable amounts. Special tests were run for Ni using ARB Method 433 and $\mathrm{Cr}$ using ARB 425; very little CrVI was found. It appears that only $80 \%$ of the fuel $\mathrm{Ni}$ was present in the exhaust sample. The nickel emission rate was $0.50-0.65 \mathrm{lb} / \mathrm{hr}$ for the bank of steam generators (about 2.2-2.8 tons/yr assuming continuous production). Annual zinc emissions would have been correspondingly less, on the same basis.

AB2588 source testing was performed on a crude-oil fired steam generator with $\mathrm{SO}_{2}$ scrubber, a natural gas fired steam generator, and two diesel engines (ENSR Consulting and Engineering, 1990). Emissions of metals, PAH, and other hydrocarbons were measured. The crude-oil fired steam generator was located in Kern County and had a low-NOx burner. Ni emissions were very similar to tests described above (69 vs $52 \mathrm{ppm} \mathrm{Ni}$ in fuel). 
Table 4 Estimated Metal Emissions

(based on tests of a 50 MBtuh unit operating for $8000 \mathrm{~h} / \mathrm{y}$ )

\begin{tabular}{|l|l|l|}
\hline \multicolumn{1}{|c|}{ Metal } & \multicolumn{1}{|c|}{$\begin{array}{c}\text { \% of } \\
\text { particulate }\end{array}$} & \multicolumn{1}{|c|}{ tpy } \\
\hline \hline $\mathrm{Al}$ & $1-100$ & $.16-1.6$ \\
\hline $\mathrm{As}$ & $0.01-0.14$ & $0.00-0.02$ \\
\hline $\mathrm{Ba}$ & $0.01-0.2$ & $0-0.03$ \\
\hline $\mathrm{B}$ & $0.003-0.03$ & $0-0.005$ \\
\hline $\mathrm{Ca}$ & $1-10$ & $0.16-1.6$ \\
\hline $\mathrm{Cr}$ & none detected & \\
\hline $\mathrm{Co}{ }^{*}$ & 0.02 & 0.003 \\
\hline $\mathrm{Cu}$ & $0.1-1$ & $0-0.16$ \\
\hline $\mathrm{Ga}$ & 0.04 & 0.006 \\
\hline $\mathrm{Fe}$ & $1-10$ & $0.16-1.6$ \\
\hline $\mathrm{Pb}$ & $0-0.006$ & 0.001 \\
\hline $\mathrm{Mg}$ & $0.3-3$ & $0.05-10.48$ \\
\hline $\mathrm{Mn}{ }^{*}$ & $0-0.02$ & $0-0.00$ \\
\hline $\mathrm{Hg}$ & $0.002-0.003$ & $0.0003-0.00048$ \\
\hline $\mathrm{Mo}$ & $0-0.07$ & $0-0.01$ \\
\hline $\mathrm{Ni}^{*}$ & $0.3-3.0$ & $0.05-0.48$ \\
\hline $\mathrm{K}$ & 0.2 & 0.03 \\
\hline $\mathrm{Se}$ & $0.001-0.002$ & 0.0003 \\
\hline $\mathrm{Si}$ & $3-30$ & $0.5-4.8$ \\
\hline $\mathrm{Ag}$ & $0-0.006$ & 0.001 \\
\hline $\mathrm{Na}$ & $<0.001$ & $<0.0002$ \\
\hline $\mathrm{Sr}$ & $0.02-0.04$ & $0.003-0.006$ \\
\hline $\mathrm{Ti}$ & $0.03-3$ & $0.05-0.48$ \\
\hline $\mathrm{V}$ & $1-10$ & $0.16-1.6$ \\
\hline $\mathrm{Zn}^{*}$ & $0.04-0.05$ & $0.006-0.008$ \\
\hline${ }^{*}=\mathrm{HAP}$ & Total & $\mathrm{HAPs}$ \\
\hline
\end{tabular}

Table 5 California Crude Oil Emissions Test Data

\begin{tabular}{|c|c|c|c|c|c|c|}
\hline \multirow[b]{2}{*}{ fuel source } & \multirow[b]{2}{*}{ API gravity } & \multirow[b]{2}{*}{$\% 5$} & \multirow[b]{2}{*}{$\%$ ash } & \multicolumn{3}{|c|}{..........metals (ppm) -......... } \\
\hline & & & & $\mathrm{Ni}$ & $\mathrm{Cu}$ & $2 n$ \\
\hline K.R. Amer. Naptha & 15.0 & 0.90 & 0.03 & 57 & 3.1 & 9.9 \\
\hline K.R. Racotrack & 14.1 & 0.72 & 0.02 & 37 & 2.5 & 8.1 \\
\hline K.R. Kem River Series & 13.4 & 1.04 & 0.03 & 70 & 4.9 & 13.0 \\
\hline $\begin{array}{l}\text { Midway Sunset } \\
\text { D\&E Sands }\end{array}$ & 13.0 & 1.30 & 0.03 & 84 & 5.0 & 9.1 \\
\hline $\begin{array}{l}\text { Mioway Sunset } \\
\text { Bremer Lease }\end{array}$ & 11.9 & 1.32 & 0.06 & 65 & 3.8 & 17.0 \\
\hline $\begin{array}{l}\text { Midway Sunset } \\
\text { Monarch } 2 f\end{array}$ & 14.5 & 1.12 & 0.03 & 81 & 3.7 & 5.8 \\
\hline Coalinga 25D & 14.2 & 0.80 & 0.02 & 28 & 3.6 & 7.6 \\
\hline San Ardo No 50's & 12.0 & 1.82 & 0.06 & 72 & 4.1 & 4.7 \\
\hline $\begin{array}{l}\text { San Ardo } \\
\text { Aurignac/Lombardi }\end{array}$ & 12.4 & 1.83 & 0.05 & 63 & 3.2 & 6.8 \\
\hline
\end{tabular}




\section{ASSESSMENT}

Since the language of the CAAA specifically exempts oil-field steam generators from the source aggregation facilities, it appears that only State regulations on toxic emissions could impact on heavy oil production. It appears unlikely that the California limit of 10 tpy might be exceeded, even if all HAPs are summed. For nickel, a bank of about 15-20 steam generators would be required to produce emissions of $10 \mathrm{tpy}$, depending on the fuel nickel content. However, it is also conceivable that particulate removal devices could be installed in such instances to bring the annual emissions under the limit. Only heavy oil production in California appears to be at issue.

A recent development (Ericksen, 1992) indicates that the steam generators used in the Bakersfield, California, area are being re-powered with natural gas in order to meet the $\mathrm{NO}_{x}$ emissions limits imposed by the 1988 California Clean Air Act. If this practice becomes widespread, the issue of direct combustion emissions from heavy oils will largely become moot in that area. Exceptions may include emissions from in situ EOR combustion (which are unlikely to reach 10 tpy for trace metals), and from off-shore facilities for which it may not be practical to repower with gas.

\section{METAL EMISSIONS FROM PETROLEUM CONSUMPTION}

The preceding discussion has focused on oil production processes. Some of the metals present in crude oil are removed in the refining process and the remainder is concentrated in the residues. As a result, residual fuel oil has the largest metal content of the various petroleum products used. Data for highly refined products such as gasoline or distillate fuels are sparse, owing in part to the typically low values.

Residual fuel oil metal emissions ( $\mathrm{V}, \mathrm{Ni}, \mathrm{Ca}, \mathrm{Na}, \mathrm{Mg}$ ) were evaluated by Dietz and Wieser (1983), for several utility boilers. They found that, in many cases, fuel metals were retained within the boiler system. They also found that the primary nickel compound emitted appeared to be nickel sulfate, which is not toxic. Data on metal content of residual fuel oils were also obtained from the Electric Power Research Institute's PISCES data base (Orr, 1992). Nickel contents ranged from 6 to $100 \mathrm{ppm}$, with an average of $24 \mathrm{ppm}$ (by weight). This was the largest HAP metal content in the data base for oil, which was limited to extant data from the literature.

Diesel fuel was evaluated as part of the emissions tests described above (Osborne and McDannel, 1990); Ni was less than $0.05 \mathrm{ppm}$ in one sample and less than $2.5 \mathrm{ppm}$ in two others. $\mathrm{Zn}$ contents were $0.75,11$, and $15 \mathrm{ppm}$. An analysis of distillate fuel oil used in combustion turbines showed less than $0.1 \mathrm{ppm}$ for $\mathrm{Ni}, \mathrm{Na}$, and V (Martin, 1992). Metal emissions from gasoline combustion were evaluated by the U.S. EPA in the 1970s as part of the evaluation of catalytic converters (Braddock, 1977). These data are typically reported in units of $\mathrm{mg} / \mathrm{mile}$; it is thus necessary to multiply by the number of miles driven in order to obtain a mass emission rate. For ca. 1990, the approximate number of vehicle miles traveled in the U.S. was $2 \times 1012$ (U.S. Statistical Abstract, 1992).

These figures on nickel emissions were converted to national totals by multiplying by the appropriate fuel (or mileage) totals. Fuel data were obtained from the 1991 State Energy Data Report (EIA, 1991). For example, total 1989 residual fuel oil consumption for the U.S. was 500 million barrels (which is more than the total U.S. heavy crude production). At an average Ni content of $24 \mathrm{ppm}$, the estimated national total of $\mathrm{Ni}$ from this source would be 2000 tons for 1989. The actual value could vary if the PISCES average were not representative and if a

\footnotetext{
- Subsequent emissions data provided by a reviewer of this report indicates that as of 1990 , about $3 / 4$ of the energy used in steam generators, heater treaters, and boilers in the San Joaquin Valley was obtained from natural gas. However, the emissions of HAPs from the remaining oil usage could be a factor in complying with proposed new stricter emission limits being considered on a statewide basis.
} 
portion of the Ni was retained within boilers, ductwork, stacks, etc. The estimated national total for gasoline was 20 tons per year; for distillate fuels, including jet fuels, 25 tons.

An estimate of ground level nickel impact from a power plant may be obtained by using "rule of thumb" meteorological dispersion factors. For a stack of about $180 \mathrm{~m}$ in height, located on the East coast (where residual fuel oil is often used), such a factor for annual average air concentrations is about $2 \times 10^{-9} \mathrm{sec} / \mathrm{m}^{3}$. The Ni emission rate for such a facility producing 1000 MW for 5000 hours per year would be about 34 tpy, which would produce an average ground level concentration of about $0.002 \mathrm{ug} / \mathrm{m}^{3}$. This figure is about one order of magnitude less than typical historical ambient levels in the Eastern United States (Akland, 1976).

\section{CONCLUSIONS AND RECOMMENDATIONS}

Heavy crude oils are an important part of the nation's present and future energy supply. In addition to higher sulfur and ash contents, these fuels are characterized by higher trace metal contents, many of which are regulated under State and Federal statutes dealing with toxic air emissions. The metal of most concern appears to be nickel, which is emitted as particles from combustion processes firing residual and crude oils.

Up to one-third of the extracted heavy crude has commonly been used to power steam generators which direct thermal energy into the reservoirs to facilitate extraction. When such facilities are aggregated in sufficient numbers, their combined emissions of nickel may exceed the California limits at which toxic emissions control regulations come into play. Although recent information indicates that oil-field steam generators are being repowered with natural gas, the continuation of this trend depends on a favorable price ratio between gas and heavy crude. This practice may not be in the nation's long-term best interest, since it involves using a "clean" (i.e., environmentally desirable) fuel to produce a "dirtier" fuel.

A cursory analysis of metal emissions from the combustion of petroleum products suggests that residual fuel oil constitutes the most important source. Since much of this fuel is used near large population centers in coastal areas, these environmental impacts may be more important than those from producing oil fields.

Given the national emphasis on toxic air emissions and the potential for low-level exposures to trace metals found in oil, this inquiry should be extended to include estimates of risks, on both an absolute basis and relative to other common sources of the substances in question.

\section{ACKNOWLEDGMENTS}

This research was supported by the Office of Fossil Energy, U.S. Department of Energy. Dr. Brent Smith of the Metairie Site Office (New Orleans) was the Project Officer. The review comments of B.T. Tulloh, ARCO Oil and Gas Company, are gratefully acknowledged.

\section{REFERENCES}

G. G. Akland, Air Quality Data for Metals, 1970 Through 1974, from the National Air Surveillance Networks, EPA-600/4-76-041, U.S. Environmental Protection Agency, Research Triangle Park, NC 27711 (1976). 155 pp.

M.M. Boduszynski, Composition of Heavy Petroleums 2: Molecular Characterization, Energy and Fuels 2:597-613 (1968).

J.N. Braddock, Gaseous, Particulate, and Sulfur-Related Emissions from Non-Catalyst and Catalyst Equipped Vehicles, EPA-600/2-77-237, U.S. Environmental Protection Agency, 
Research triangle Park, NC 27711 (1977). 48 pp.

J.F. Branthaver, Influence of Metal Complexes in Fossil Fuels on Industrial Operations, in Metal Complexes in Fossil Fuels, R.H. Filby and J.F. Branthaver, eds., 1986. pp.188-204.

I.A. Breger, Geochemical Considerations Regarding the Origin of Heavy Crude Oils; Suggestions for Exploration. pp. 163-167. in The Future of Heavy Crude and Tar Sands, Proceedings of the 1st International Conference, June 1979, Edmonton, Alberta, Canada. Unitar. McGraw Hill, New York. 915 pp.

E. Edler, Geochemistry of Inorganic Trace Elements. in International Symposium on Vanadium and other metals in Petroleum. Volume II. Chemistry and Physics. Instituto de Investigaciones Petroleras, Universidad del Zulia, Maracaibo-Venezuela, Aug. 1973.

Energy Information Administration, State Energy Data Report, DOE/EIA-0214(89), Washington, DC (1991). $471 \mathrm{pp}$.

L. Erickson, San Joaquin Valley Unified Air Pollution Control District, personal communication, March 26, 1992.

ENSR Consulting and Engineering, Pooled Source Emission Test Report: Oil and Gas Production Combustion Sources, Fresno and Ventura Counties, California. report to Western States Petroleum Association, Dec. 1990.

A. Goodley, Air Quality Impact of Thermally-Enhanced Heavy Oil Recovery in California, U.S.A. pp. 744-750. in The Future of Heavy Crude and Tar Sands, Proceedings of the 1st International Conference, June 1979, Edmonton, Alierta, Canada. Unitar. McGraw Hill, New York. $915 \mathrm{pp}$.

W.E. Harrison, C.J. Mankin, S.J. Weber, and J.A. Curiale, Oil Sand and Heavy-Oil Potential of Oklahoma. pp. 83-89. in The Future of Heavy Crude and Tar Sands, Proceedings of the 1st International Conference, June 1979, Edmonton, Alberta, Canada. Unitar. McGraw Hill, New York. 915 pp.

C.R. Hocott, Heavy Oil - The Next Frontier: What Will It Cost?, pp. 771-774 in The Future of Heavy Crude and Tar Sands, Proceedings of the 1st International Conference, June 1979, Edmonton, Alberta, Canada. Unitar. McGraw Hill, New York. 915 pp.

J. Hutchins, U.S. Energy Information Administration, personal communication, May 18, 1992.

P. Jones, The presence of trace elements in crude oils and allied substances, Quart.J. Technical papers, Inst. Petroleum, pp.73-76 (1986).

E. Kaplan, M. Garrell, B. Royce, E.F. Riedel, and J. Sathaye, Assessment of Environmental Problems Associated with Increased Enhanced Oil Recovery in the United States: 1980-2000, BNL 51528, Brookhaven National Laboratory, Upton, NY January 1983. 142 pp.

G. Martin, LILCO, personal communication, May 1992.

R.F. Meyer and W.B. Dietzman, World Geography of Heavy Crude Oils, pp. 16-28. in The Future of Heavy Crude and Tar Sands, Proceedings of the 1st International Conference, June 1979, Edmonton, Alberta, Canada. Unitar. McGraw Hill, New York. 915 pp.

D.A. Orr, Radian Corp., personal communication, April, 1992. 
W.E. Osborne and M.D. McDannel, Emissions of Air Toxic Species: Test Conducted Under AB2588 for the Western States Petroleum Association, May 1990. CR 72600-2061.

J.G. Speight (1990), Fuel Science and Technology Handbook, M. Dekker, New York. 1193 pp. UNITAR/UNDP, International Survey of Heavy Crude and Tar Sands, 1984. New York. 179 pp.

U.S. Bureau of Mines, Heavy Crude Oil, Resource, Reserve, and Potential Production in the United States, Petroleum Staff, Mineral Resource Offices, Information Circular 8352, 1967.

H.K. van Poollen and Associates, Inc., Fundamentals of Enhanced Oil Recovery, Pennwell Publishing, Tulsa, OK 1980.

T.F. Yen, The Role of Trace Metals in Petroleum, Ann Arbor Science Publishers, 1975. 221 pp. 
Appendix A

Toxic Substances Regulated Under the Clean Air Act (Title III of the 1990 Amendments)

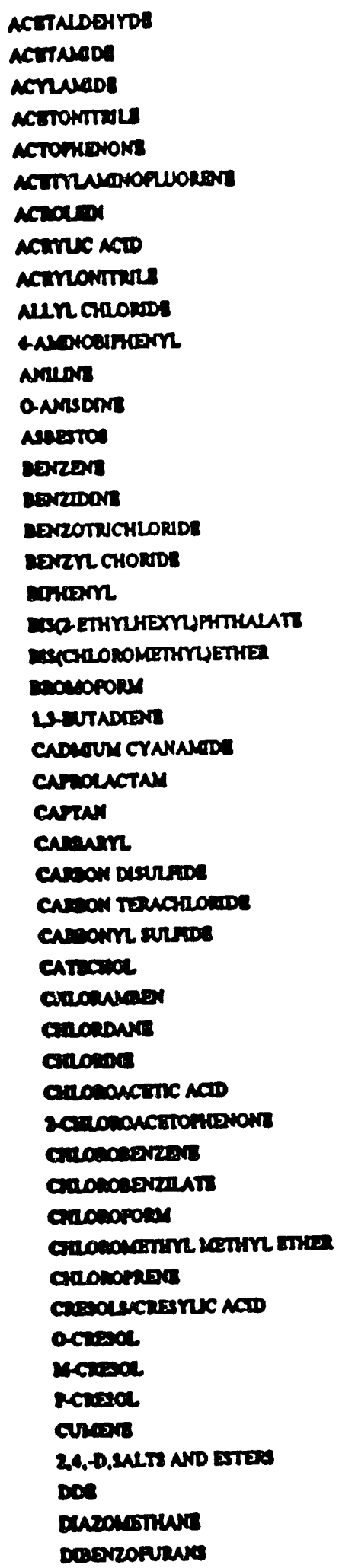

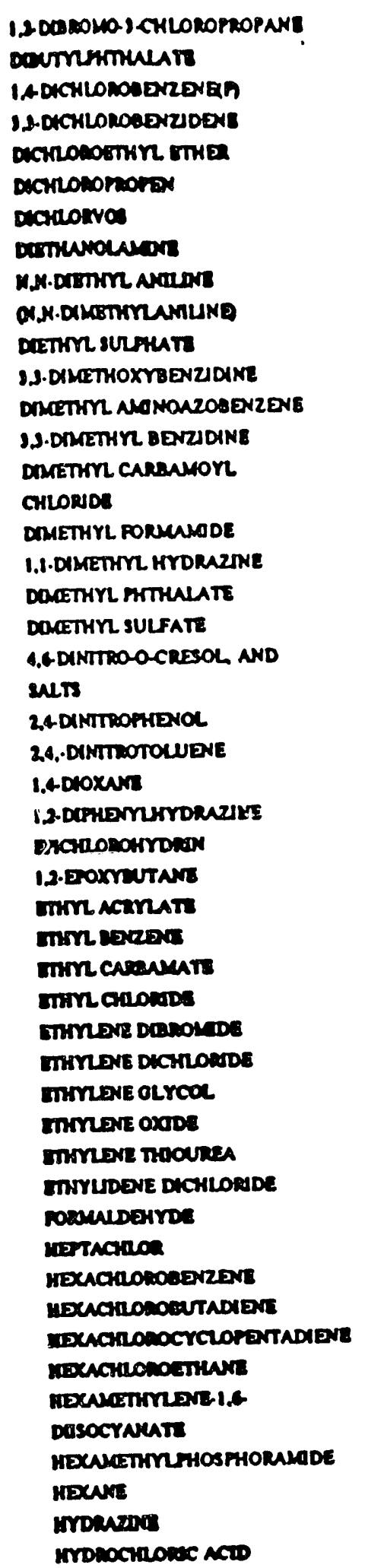

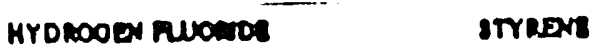

MYDRoquinom

ISOPHONOME

UNDANe Wel Bonded

MUSC ANHOate

renuwat

METHarranom

Metrin mover

Mentr. chlow

METHYL CHLONOFONH

METHY ETHYLETONE

METHY KYDQUTE

METHYL DONDE OOOOMETHUND

MEHTY LOOUT' KETONE

METHY ISCOYALAT

METHY METHCOTIUT:

METHYUNETHCACTYLT

METHY TEXT WTI ETKER

4.4-METHYLNE ESR.

CHLORONIUNE

METH VIOE CYOONDE

METHYIONE DUHIOM

4.9'.METH YLONEOU VIUNE

MAPHTHLLNE

MITRODERTE

4 NTIDountom

4MTIDOMTONL

2. NTImomopare

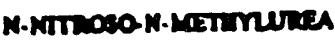

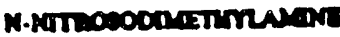

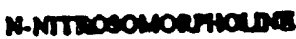

Paratrocen

rortachonoramberzare

Partachosontzece

manol

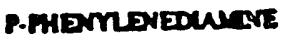

mosoger

mostrane

mosmows

minuace arotrodo

rolYchLouRuteo aribors

13-PLOPANE gULTOSE

META-rionolactore

moroinederrve

mopoxur aurocms

momere dochonde

moOr DNE OADE

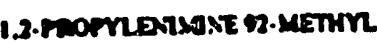

quruounse

curvoms
ITrRave OXDS

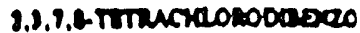
moxan

1.1.2.2 minecraonoetrua Truanomocrinm

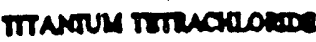
rowere

24 Tourers oulan

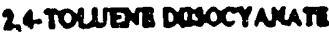

a rouroar

Toxamer

1.2.4 Tuchoscoserse

1.1.2- TnCHLONotThe

THCWLONOETMON

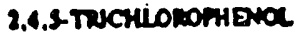

2.4.4 TUECHLOROHENCL

TRETHYUNAN

TRruten:

2,2,4-TULETHTUNOTARe

Varn ACETATE

MNY BRONADE

VWr CHONDE

VIMDONE CKLOHDE

(1.1-Dichlosoenmose

xnove

axruare

HXYvó

Axrove.

Armeorr congorst

Aresec conoumbe

cenrurs cospour is

CADidus conocentes

croosours condourmes

COenet COMDOUNR

cosis ovar Daserons

crandide conoounds

OLYCOL EmIJS

IFAD CONOONDS

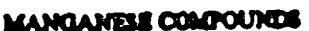

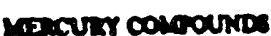

Fre IONDal Foas

mace conocurpo

notrenc coannc mar

moronucudos ancuto

unows

sandur con rountos 

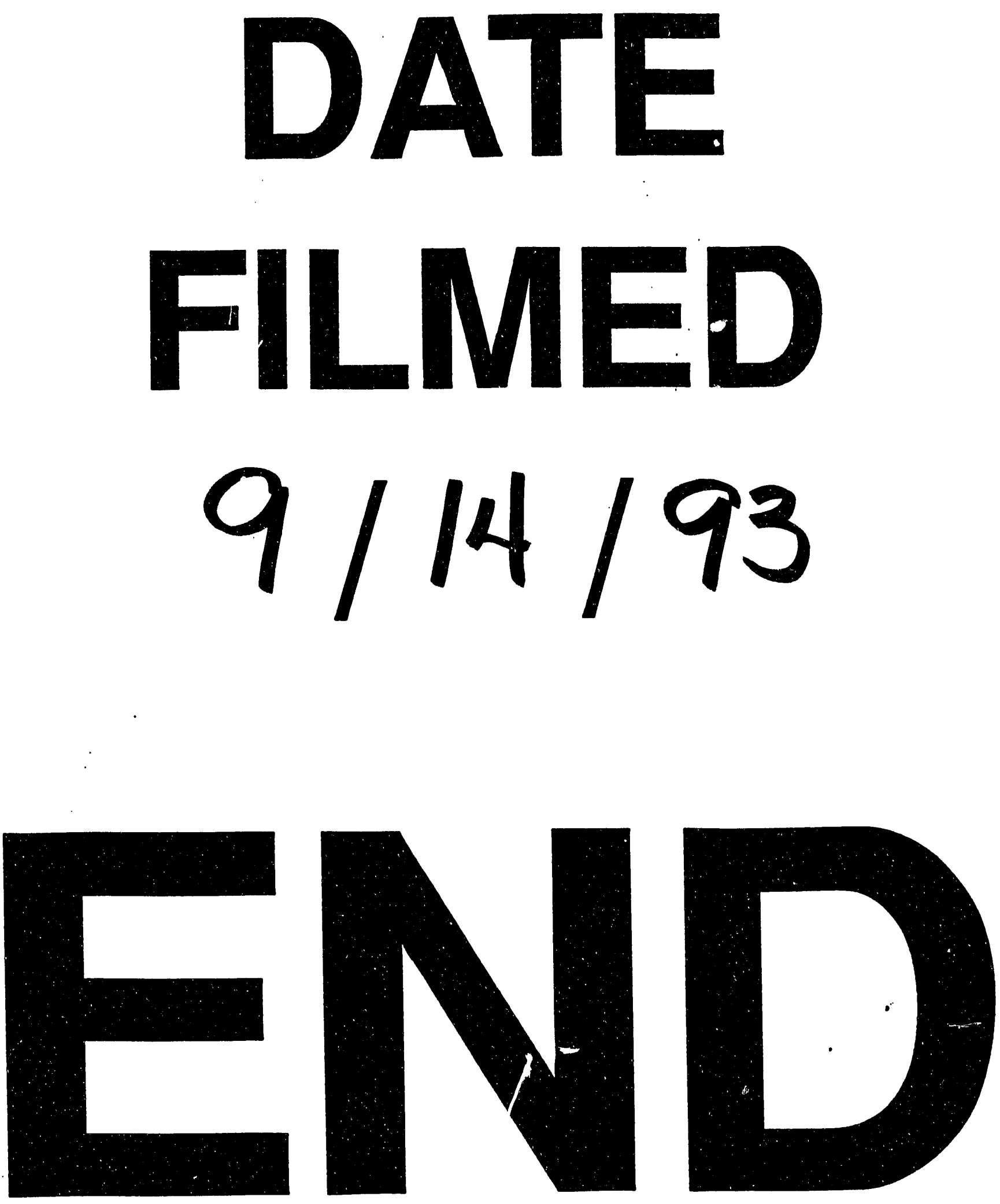
